\title{
A universal flu vaccine
}

\author{
Malgorzata Kesik-Brodacka ${ }^{\bowtie}$ and Grazyna Plucienniczak \\ Department of Bioengineering, Institute of Biotechnology and Antibiotics, Warsaw, Poland
}

\begin{abstract}
Influenza is a global health concern. The single most effective way of protecting people against influenza infection and disease is vaccination. However, currently available vaccines against influenza induce only strain-specific immunity, and do not elicit long-lasting serum antibody titers. Therefore, they are ineffective in the case of possible pandemics. There is an urgent need for a new generation vaccine which would induce broad and longlasting immune protection against antigenically distinct flu viruses. The paper presents recent achievements and the challenges in the field of universal vaccine construction.
\end{abstract}

Key words: universal vaccine, flu vaccine, influenza virus

Received: 01 June, 2014; revised: 27 August, 2014; accepted: 28 August, 2014; available on-line: 09 September, 2014

\section{INTRODUCTION}

Influenza is a global health concern, with the annual attack rate estimated at $5 \%-10 \%$ in adults and $20 \%$ $30 \%$ in children. Illness can result in hospitalization and death, especially among high-risk groups: the very young, elderly or chronically ill (Thompson et al., 2004; Zhou et al., 2012). It is estimated that each year influenza infections cause for 3 to 5 million cases of severe illness and 250000 to 500000 deaths worldwide (http://www.who. int/mediacentre/factsheets/fs211/en/). The European Centre for Disease Prevention and Control estimates that, on average, nearly 40000 people die prematurely each year from influenza in countries of the European Union (EU) and the European Economic Area (Mereckiene et al., 2014). Given its disease-causing potential, the prevention of infection with influenza viruses is a high public health priority. Currently, the most effective single way of protecting people against influenza infection and disease is vaccination (Nicoll et al., 2013; Cox et al., 1999). The influenza virus belongs to the family Orthomyxoviridae (Lamb et al., 2001) and is divided into the $\mathrm{A}, \mathrm{B}$ and $\mathrm{C}$ genera, which are distinguishable on the basis of antigenic differences between their matrix and nucleoproteins ( $\mathrm{M}$ and $\mathrm{NP})$, their host range, variations in surface glycoproteins, genome organization and morphology. Within the influenza virus genera, influenza $A$ and $B$ viruses are the most relevant clinically because they cause severe respiratory infections in humans (Hampson et al., 2006). Of the two, type A viruses are more virulent, cause the most severe disease and are the primary pathogens responsible for seasonal and pandemic influenza outbreaks (Hayashida et al., 2001; Wright et al., 2001).
Type A viruses can be divided into different subtypes based on the serotypes of their main surface antigens: hemagglutinin (HA) and neuraminidase (NA) (Hayashida $\mathrm{H}$ et al., 1985). So far, $18 \mathrm{HA}$ and $9 \mathrm{NA}$ subtypes have been identified. Phylogenetically, HA subtypes are categorized into two groups (H1, H2, H5, H6, H8, H9, H11, $\mathrm{H} 12, \mathrm{H} 13, \mathrm{H} 16, \mathrm{H} 17$, and $\mathrm{H} 18$ in group 1 , and H3, H4, H7, H10, H14, and H15 in group 2) (Medina et al., 2011; Huber, 2013; Tong et al., 2013; Pica et al., 2013). Historically, H1 (H1N1), H2 (H2N2) and H3 (H3N2) strains have caused influenza pandemics in humans and resulted in millions of deaths (Steel et al., 2010).

Influenza B viruses have diverged into two antigenically and phylogenetically distinct lineages that co-circulate in the environment (Rota et al., 1990; Hay et al., 2001; Kanegae, et al., 1990). Infections caused by influenza B viruses are less severe, but the pathogen can still cause outbreaks. The influenza $\mathrm{C}$ virus is of little concern for human infections, causing only a mild common cold-like disease in children (Moriuchi et al., 1991).

\section{DISADVANTAGES AND LIMITATIONS OF CURRENTLY AVAILABLE VACCINES}

Currently available vaccines against influenza are poorly immunogenic and do not induce long-lasting serum antibody titers. They provide protection only against a subset of strains circulating in the environment, namely, those closely related to the vaccine strains. This limited effectiveness is due to a mechanism called antigenic drift: the influenza virus undergoes genetic variations, allowing it to evade the pre-existing immune responses of the host. Therefore, immune responses mounted against earlier forms of the virus are less effective or completely ineffective against newer variants. Thus, a new vaccine must be reformulated and prepared every flu season. Besides, the vaccine has to be based on a surveillance of antigenic drift and predictions of the dominant strain for the upcoming flu season (Russell et al., 2008). The strains are selected by a network of experts several months in advance before the next influenza season regarding the duration of the manufacturing process. Although the process of antigenic drift is well studied, precise predictions of what strains will circulate in a given season remains problematic. Mismatches between vaccine strains and circulating viruses occur, resulting in a sharp drop in vaccine efficacy (de Jong et al., 2000; Ram Yogev, 2005; Carrat et al., 2007). Moreover, current vaccines appear to be less effective in the elderly (Centers for Disease

e-mail: kesikm@iba.waw.pl

Abbreviations: HA, hemagglutinin; NA, neuraminidase; bnAbs, broadly neutralizing antibodies; VLPs, virus like particles; $\mathrm{HBC}$, hepatitis B core antigen; KLH, keyhole limpet hemocyanin; MVA, Modified vaccinia virus Ankara; PB1, polymerase basic protein 1 
Control and Prevention Morb. Mortal. Wkly. Rep. 62, 119-123 (2013)).

It is also important to note that currently available vaccines do not protect against possible pandemics resulting from genetic variations between different subtypes of the influenza virus concurrently infecting the same host (Shapshak et al., 2011). Additionally, it takes at least 6-8 months to develop, test and produce conventional vaccines against emerging viruses (Krammer et al., 2014). The reformulation of the annual flu vaccine is also an expensive undertaking that costs consumers and the global health system more than $\$ 4$ billion each year (Hoag, 2013).

Despite these drawbacks, influenza vaccination has been demonstrated to be highly cost-efficient and cost saving (Nichol et al., 2007; Scuffham et al., 2002). In December 2009, the European Council unanimously recommended that EU countries adopt and implement national action plans to achieve $75 \%$ influenza vaccination coverage in all at-risk groups by the influenza season of 2014/15 (Official Journal of the European Union L348: 71-72). The US Centers for Disease Control Prevention recommended universal influenza vaccination for all persons at least 6 months of age (Fiore et al., 2010). Despite the availability of safe and relatively effective vaccines and the recommendations of official health sources, seasonal influenza vaccination coverage rates remain suboptimal and generally well below the WHO and US targets. During the $2012 / 2013 \mathrm{flu}$ season in the USA, flu vaccination coverage was 45\% (http://www.cdc.gov/flu/fluvaxview/ coverage-1213estimates.htm\#estimated). According to information from the National Institute of Public Health, in the $2012 / 2013$ flu season, $3.75 \%$ of the Polish population was vaccinated against influenza. It demonstrated that even the $2009 / 2010$ A/H1N1 pandemic had little effect on the coverage rates for the seasonal influenza vaccine (Blank et al., 2012).

\section{EFFICACY OF CURRENT INFLUENZA VACCINES}

The efficacy rate of available in the USA influenza vaccines is approximately $59 \%$ for adults (Osterholm et al., 2012; Jefferson et al., 2010). Yet, vaccine effectiveness against $\mathrm{H} 3 \mathrm{~N} 2$, the main flu strain circulating during the $2012 / 2013$ season, proved to be only $46 \%$ for adults aged $18-49,50 \%$ for those aged 50-64, and a dismal $9 \%$ for people aged over 65 , who represent a vulnerable group (Centers for Disease Control and Prevention 2013; http://www.cdc.gov/mmwr/preview/mmwrhtml /mm6207a2.htm?s_cid=mm6207a2_w.; Kissling et al., 2014). However, the suboptimal vaccine effectiveness for the H3N2 component during the $2012 / 2013$ season was related to mutations in the egg-adapted IVR-165 vaccine strain (Skowronski et al., 2014).

The low effectiveness of currently available flu vaccines results, among other reasons, from the low use of the seasonal influenza vaccine. This is caused by the necessity of yearly vaccine re-administration, related cost issues, lack of influenza vaccine acceptance in the general population, and unknown efficacy for a given season. Sensational media coverage and public debate concerning vaccine effectiveness, which depends on the match between the circulating virus and the vaccine strains, can negatively impact vaccination coverage (Kissling et al., 2011; Kissling et al., 2011). Another problem, especially in European countries, is the public attitude to the adjuvants present in vaccines. Thus, in the event of a pandemic, vaccination could be ineffective. To overcome the limitations of seasonal influenza virus vaccines and enhance our pandemic preparedness, we need a vaccine that provides universal and durable protection.

\section{UNIVERSAL VACCINE}

The development of a universal vaccine is one of the major goals in global pandemic preparedness plans. A universal flu vaccine could provide protection regardless of the strain or subtype of the circulating virus, allowing the vaccine to be prepared in advance in appropriate amounts, and be ready to use "off-the-shelf" in the event of a pandemic (Epstein et al., 2010).

It is expected that a universal flu vaccine would have several advantages over currently available seasonal vaccines. The universal vaccine would require less frequent administration, ideally only once. This would reduce the exposure of vaccinated individuals to adjuvants and would eliminate the recurring cost of yearly vaccination. These features could increase public acceptance of vaccination against the flu and thereby augment flu vaccine coverage.

\section{CONSERVED INFLUENZA ANTIGENS}

The development of universal vaccines relies on the utilization of highly conserved antigenic targets (Epstein, 2003; Heiny et al., 2007). However, conserved antigen epitopes are usually less exposed to the host immune system, and as such, are naturally weakly immunogenic. The goal of a universal vaccine is to augment their immunogenicity sufficiently to induce protective immunity.

Several proteins encoded by the influenza virus have been evaluated as promising candidate antigens for the development of a universal vaccine. Among them are the HA, M (M1 and M2e), NP and NA proteins. All of the listed antigens have highly conserved regions that are potential immunogens for a universal vaccine.

\section{STRUCTURE OF THE HA ANTIGEN}

Hemagglutinin, the major envelope glycoprotein of influenza A viruses, is the target of almost all neutralizing antibodies. HA is synthesized as an immature polypeptide chain called HA0, which is activated upon cleavage by host proteases to yield two subunits, HA1 and HA2. HA2 creates a helical chain "stem" that is anchored in the viral lipid membrane. The HA1 subunit of HA forms a globular "head" that contains receptor binding sites and the majority of the virus antigenic sites (Wiley et al., 1981). Because HA1 loops are highly variable, antibodies targeting these regions are strain-specific, explaining why immunity by natural exposure or vaccination is typically restricted to the currently circulating strains. It has been estimated that human seasonal $\mathrm{H} 3$ and $\mathrm{H} 1$ viruses have undergone between $2.1 \%$ and $3 \%$ amino acid changes per drift variant between 1999 and 2010 .

In contrast to HA1, the HA2 subunit is highly conserved among viruses belonging to the same phylogenic group. It also undergoes mutations, although at a much lower rate. It underwent only 3 different amino acid changes in this region in the $\mathrm{H} 1$ and $\mathrm{H} 3$ strains in the same period of time (Han et al., 2011). Furthermore, HA2 is also immunogenic (Russ et al., 1987). Indeed, the stem region of HA represents a promising target for 
universal vaccine design eliciting broadly cross-reactive neutralizing antibodies directed against an epitope in this region of HA (Gerhard et al., 2006; Krystal et al., 1982).

\section{THE PURSUIT OF AN ANTIBODY THAT TARGETS CONSERVED REGIONS}

The first report describing an antibody cross-reactive with the HA stem was published by Yoshinobu Okuno (Okuno et al., 1993). The mouse antibody C179 neutralizes the $\mathrm{H} 1, \mathrm{H} 2, \mathrm{H} 5, \mathrm{H} 6$, and $\mathrm{H} 9$ subtypes of the virus (Okuno et al., 1993; Sakabe et al., 2010; Smirnov et al., 1999). The idea of cross reactive antibodies became popular when, five years ago, six independent groups began to publish data on existence of human antibodies capable of neutralizing many different subtypes of the influenza virus. Broadly neutralizing antibodies (bnAbs) neutralizing viruses belonging to HA phylogenetic group 1 (mAb CR 6261 and F10) (Sui et al., 2009; Throsby et al., 2008; Kashyap et al., 2008; Ekiert et al., 2009), group 2 (CR 8020, CR8043) (Ekiert et al., 2011; Friesen et al., 2014), and group 1 as well as group 2 (mAb FI6) (Corti et al., 2011; Russell, 2011; Clementi et al., 2011) were identified. The identification of antibodies that can bind to both influenza virus groups is important, as the influenza A viruses responsible for human pandemics derive from both group 1 (H1N1 and H2N2) and group 2 (H3N2). In addition, zoonotic viruses from both groups can infect humans and have the potential to trigger future pandemics (including $\mathrm{H} 5 \mathrm{~N} 1$ and H9N2 from group 1 and H7N7 from group 2). Consequently, future universal therapies based on the FI6 antibody have the potential to provide protection against both group 1 and group 2 influenza viruses (Corti et al., 2011).

Similarly, antibodies (CR8033 and CR8071) were identified as recognizing conserved epitopes in the HA head region of influenza B (Dreyfus et al., 2012). Furthermore, an antibody (CR9114) that recognizes epitopes in the HA stem of both influenza $A$ and influenza B, and which protects against lethal challenges from both of these genera, was discovered (Dreyfus et al., 2012). CR9114 is the most broadly neutralizing antibody identified so far.

In addition to cross-reacting antibodies which bind to the conserved regions of HA2, broadly neutralizing antibodies that recognize regions on HA1 were also identified (Ohshima et al., 2011; Ekiert et al., 2012; Lee et al., 2012; Tsibane et al., 2012).

It has been shown that such broadly cross-reactive HA stem antibodies provide protection through passive transfer (Ekiert et al., 2011; Corti et al., 2010; Sui et al., 2009; Wang et al., 2010; Corti et al., 2013).

\section{UNIVERSAL VACCINES BASED ON HA ANTIGEN}

The identification of bnAbs against influenza viruses has raised hopes for the development of the universal vaccines for influenza. It was shown that bnAbs recognizing the HA stem, can be elicited after influenza infection in humans, although they are produced at low levels (Ohshima et al., 2011; Sui et al., 2011; Corti et al., 2013). The natural occurrence of bnAbs has inspired construction of a vaccine that would exclusively induce bnAbs, i.e., a universal vaccine. Such a vaccine could potentially provide a long-lasting protection; a recent study showed that a high titer stem-reactive antibodies induced by an influenza virus vaccine were detectable after more than 30 years (Miller et al., 2013).

Two approaches are used when developing a universal vaccine based on the HA antigen. One approach involves the use of full-length $\mathrm{HA}$, and the other focuses on the HA conserved stem domain. Both of these approaches are associated with low level of neutralizing antibodies that recognize conserved regions on the HA stem. When using full-length HA, considerably lower levels of immunological response are achieved to the HA stem than to the head because the HA head physically masks the stem region on the influenza virion (Kwong et al., 2009). There have been some attempts to use full length HA to elicit a broad neutralizing response.

In one such approach adenovirus vectors expressing centralized consensus influenza antigens representing putative HA ancestors were used. Centralized HA antigens were obtained from synthetic full-length HA sequences within a subtype or among different subtypes. The proposed vaccine provided protection that was limited to viruses within the same subtype (Weaver et al., 2011). Another approach using the full-length HA antigen is DNA vaccine technology (Chen et al., 2008).

It is challenging to induce immunological responses to conserved regions that are weakly immunogenic. There are currently several strategies employed for stem-oriented antigen design that eliminate the dominant immune response to the HA head. One such strategy is the use of a truncated HA that lacks the globular head domain, but still maintains the integrity of the stem region. Such a headless HA antigen derived from H2N2 was expressed in CV-1 cells and detected with the C179 antibody that neutralizes all $\mathrm{H} 1$ and $\mathrm{H} 2$ subtypes. Mouse experiments revealed that the mice were protected from the homologous virus and partially protected from the H1N1 virus (Sagawa et al., 1996).

In another example, mice were vaccinated with a combination of DNA and Virus Like Particles (VLPs) expressing a headless HA construct derived from $\mathrm{H} 1 \mathrm{~N} 1$ and $\mathrm{H} 3 \mathrm{~N} 2$ viruses. Immunization elicited antisera that were cross-reactive against multiple group 1 subtypes of hemagglutinin, and provided protection against homologous lethal challenges (Steel et al., 2010). Schneemann et al. used a multivalent display of a 20-residue A-helix from HA2 on icosahedral VLPs derived from the capsid of the Flock House virus to immunize mice. The 20-residue A-helix of HA2 is the major component of the epitopes of the broadly neutralizing antibodies CR6261, F10, and others. It was shown that immunization with VLPs displaying 180 copies/particle of the A-helix elicited antibodies recognizing multiple HA subtypes from group 1, but not from group 2. However, the elicited antibodies did not neutralize the influenza virus (Schneemann et al., 2012). In another attempt, a stable trimeric influenza hemagglutinin stem domain was produced through the T4 bacteriophage fibritin foldon fusion at the C-terminus of the HA stem domain (Lu et al., 2014).

Selected peptides corresponding to HA conserved regions can be used to construct a universal vaccine. They can be fused with carrier proteins, such as keyhole limpet hemocyanin $(\mathrm{KLH})$, for improved antigen presentation, and enhanced immunogenicity based on the adjuvant function of the carrier proteins. It was shown that KLH fusion protein comprising an HA2 synthetic peptide from an $\mathrm{H} 3$ virus conferred heterosubtypic protection against $\mathrm{H} 5$ and $\mathrm{H} 1$ viruses (Wang et al., 2010). Bommakanti et al. designed an HA2-based immunogen derived from the sequence of H3N2, which was expressed in Es- 
cherichia coli and refolded from inclusion bodies. The obtained antigen provided protection against a homologous $\mathrm{H} 3$ viral challenge and also provided cross-strain protection within the subtype (Bommakanti et al., 2010).

Vaccines based on the HA antigen aiming to elicit an immunological response against the HA conserved domain have the potential to be developed. Even if the immunological response to the HA stem is weak, this response could be augmented by boosting with vaccines that exclusively induce bnAb HA stem antibodies. This theory is supported by data demonstrating that individuals infected with pandemic 2009 IAV experienced a boost in virus-neutralizing antibodies specific to the HA stem (Pica et al., 2012). This phenomenon has also been confirmed in a mouse model of sequential infection (Krammer et al., 2012; 2014).

In accordance with these results, it may be necessary to preimmunize individuals naive to the influenza virus (such as children) before vaccinating them with a universal vaccine.

Additional aspect is the safety of next-generation influenza vaccines based on HA stem domain antigens. Generally, antigens induce antibody responses including both neutralizing and non-neutralizing antibodies. Recent studies demonstrated that non-neutralizing antibodies may be associated with enhanced infectivity (To et al., 2012). It was reported that whole inactivated H1N2 virus vaccination and subsequent challenging with $\mathrm{H} 1 \mathrm{~N} 1$ resulted in more frequent and more severe vaccine-associated pneumonia. (Khurana et al., 2013). It was suggested that elicited non-neutralizing anti-stalk antibody might promote H1N1 infection by enhancing H1N1 virus membrane fusion activity. As these results imply, it is of great importance from the safety point of view that we ought to understand fully the molecular basis for neutralization of influenza viruses in polyclonal responses in vivo.

\section{UNIVERSAL VACCINES BASED ON M2e ANTIGEN}

The extracellular domain of the M2 protein (M2e) may be the most explored target for a universal influenza vaccine. Interest in this protein as a vaccine target was triggered by observations that anti-M2 antibodies, while lacking neutralizing activity, reduce plaque size (Zebedee et al., 1988), and the level of replication of a challenge virus in the lungs of mice (Treanor et al., 1990; Wang et al., 2008). Moreover, this protein is relatively well conserved across viral strains. As an example, the $\mathrm{N}$ (amino)-terminal epitope SLLTEVET (residues 2-9) in M2e was found to be $100 \%$ conserved among human influenza A virus and over 99\% among all influenza A subtypes (Fiers et al., 2004; Liu et al., 2005).

$\mathrm{M} 2$ is a tetrameric integral membrane protein that functions as a pH-dependent proton channel, and is a minor component of the virus envelope. The protein is essential for proper maturation of the HA, for uncoating the virus after viral entry, and for releasing the viral genome into the cytoplasm (Lamb et al., 1985; Schnell et al., 2008). M2e, while exposed on the virion surface, in 1 to 3 copies, is masked by HA and NA proteins (Song et al., 2011). These factors may explain why anti-M2 or anti-M2e antibody levels are very low in influenza-infected humans and animals. However, mouse model studies showed that anti-M2 antibodies have a protective nature; animals vaccinated with baculovirus-derived M2 were protected from lethal challenge with $\mathrm{H} 1 \mathrm{~N} 1$ and $\mathrm{H} 3 \mathrm{~N} 2$ influenza viruses (Slepushkin et al., 1995). Unfortunately, the extension of these studies to other laboratory animals, including ferrets and primates, was not encouraging (Fan et al., 2004). Nevertheless, studies in most animal models indicate that M2e-based vaccines reduce morbidity levels, but do not confer immunity to infection. However, pigs immunized with M2e-derived human or avian viruses showed no protection against challenge with a swine virus, although the anti-M2 antibody levels were increased (Heinen et al., 2002; Hikono et al., 2012). Differences in the M2e sequences between the vaccine and the challenge virus could explain why no protection was observed in this case.

M2e in its virion-bound form is poorly immunogenic (Rossman et al., 2011). Therefore, several approaches have been proposed to improve the immunogenicity of M2, including the addition of adjuvants (Slepushkin et al., 1995; Wu et al., 2007; Wu et al., 2009), fusing the peptide to known highly immunogenic carrier proteins, and employing genes that target and improve immune function (hepatitis B core antigen $(\mathrm{HBc})$, KLH (Tompkins et al., 2007), bacterial outer membrane complex (Fu et al., 2009), and flagellin (Huleatt et al., 2008), VLPs (human papillomavirus L protein VLPs (Ionescu et al., 2006), phage Q $\beta$-derived VLPs (Bessa et al., 2008)), or liposomal platforms (Ernst et al., 2006).

In one approach, to improve hetero-subtypic crossprotection, VLPs were used. The expressed tandem repeats of M2e peptides containing two human, two avian and one swine origin M2e sequences fused to the HA transmembrane and cytoplasmic domains (Kim et al., 2013). The M2e proteins incorporated into these VLPs were 100 times more abundant than they were in influenza virions. This study showed that sera from mice immunized with such chimeric VLPs reacted with a range of influenza viruses, including $\mathrm{H} 1 \mathrm{~N} 1, \mathrm{H} 3 \mathrm{~N} 2$ and $\mathrm{H} 5 \mathrm{~N} 1$ strains.

In another approach, different forms of VLPs based on the $\mathrm{M} 2 \mathrm{e}$ antigen fused to $\mathrm{HBc}$ were shown to induce high levels of anti-M2e antibody responses (Fiers et al., 2004; Neirynck et al., 1999; de Filette et al., 2006; de Filette et al., 2005; Heinen et al., 2002). Nevertheless, the protection against infection mediated by M2e was not complete. There is also ongoing research directed at understanding the mechanism of M2e-specific immunity. It was shown that antibodies recognizing M2 do not neutralize the virus. Several theories explaining the protection mechanism were proposed, including antibody-dependent cell cytotoxicity, antibody-dependent natural killer cell activity, and complement-mediated lysis Jegerlehner et al., 2004; Tompkins et al., 2007; El Bakkouri et al., 2011).

Research on M2e-based universal vaccines has produced several minor successes. For example, in a double-blind, placebo-controlled phase I clinical trial, the safety and immunogenicity of M2e-HBc VLPs combined with adjuvant, derived from recombinant cholera toxin A1, were evaluated in humans, and the results demonstrated that this approach was promising for further clinical studies. Another candidate, STF2. $4 \times$ M2e, a fusion protein of M2e with the TLR5-ligand domains from Salmonella typhimurium flagellin $\mathrm{flj} \mathrm{B}$, also completed a phase I clinical trial, and was found to be safe and immunogenic (Huleatt et al., 2008; Rupp et al., 2011; Talbot et al., 2010).

It is of great importance to test the effectiveness of new universal flu vaccine strategies in clinical trials, as it is almost impossible to mimic the human situation using animal models. 


\section{UNIVERSAL VACCINES BASED ON NP AND M1 ANTIGENS}

Phylogenetic analysis of virus strains isolated from different hosts indicates that the NP and M1 genes are relatively well conserved, with a maximum amino acid difference of less than 11\% for NP (Shu et al., 1993), and only about 5\% for M1 (Reid et al., 2002). Therefore, they are attractive candidates for a broad-spectrum influenza vaccine (Shu et al., 1993; Heiny et al., 2007; Price et al., 2009). The NP protein is able to elicit subtype crossreactive cytotoxic $\mathrm{T}$ lymphocyte immunity to speed up viral clearance in mice and humans (McMichael et al., 1983; Ulmer et al., 1998). It was also demonstrated that NP induces non-neutralization antibodies, which play a role in heterosubtypic immunity in mice (Carragher et al., 2008). Recently, multi-antigen constructs employing NP and M1 antigens have shown promise in conferring broad protection against influenza subtypes.

Modified vaccinia virus Ankara (MVA) vectors expressing various combinations of NP, M1, HA and NA have been evaluated in animal models (Boyd et al., 2013; Brewoo et al., 2013). Phase I and II clinical studies of an MVA expressing NP+M1 indicate that this approach is safe and might be efficacious for preventing influenza infection in humans (Berthoud et al., 201; Lillie et al., 2012).

Furthermore, MVA vectors expressing influenza NP alone or co-expressed with other conserved influenza proteins (e.g., the stem region of HA, proteins M1 and $\mathrm{M} 2$, the viral polymerase basic protein 1 (PB1), or the $\mathrm{HA}$ stem fused to a quadrivalent M2e) protect mice against lethal challenges with $\mathrm{H} 5 \mathrm{~N} 1, \mathrm{H} 7 \mathrm{N1}$ and $\mathrm{H} 9 \mathrm{~N} 2$ viruses by a mechanism involving influenza-specific CD4+ and CD8+ T cell responses (Hessel et al., 2014).

\section{UNIVERSAL VACCINES BASED ON NA ANTIGEN}

Although a vaccine based on NA is also being developed, this antigen alone is considered to have little potency in preventing infection (Johansson et al., 2011).

Nevertheless, it has been shown that NA-specific antibodies restrict viral replication by preventing the release of progeny from infected cells, which limits viral spread and shortens the severity and duration of illness (Powers et al., 1996; Kilbourne et al., 1968; Murphy et al., 1972; Couch et al., 1974; Webster et al., 1988). It was shown that the administration of N1-VLP particles induced the production of NA antibodies that confer significant cross protection against $\mathrm{H} 5 \mathrm{~N} 1$ and $\mathrm{H} 1 \mathrm{~N} 1$ (Wu et al., 2012). The immunization of mice with VLPs containing the N1 NA antigen induced the production of an antibody recognizing $\mathrm{H} 1 \mathrm{~N} 1$ and $\mathrm{H} 3 \mathrm{~N} 2$ viruses as well as protected against lethal infection by the homologous H1N1 and heterosubtypic H3N2 (Quan et al., 2012).

\section{CONCLUDING REMARKS}

The development of a universal vaccine against influenza viruses is challenging. Although promising research is in progress, there is still no commercially available vaccine protecting against a wide spectrum of influenza viruses. In 2013, Jesse Goodman, Chief Scientist at the U.S. Food and Drug Administration, predicted that a universal flu vaccine was still 5 to 10 years away. Given the disease-causing potential of the type $A$ and $B$ virus strains, vaccination against both of these virus types is a high public health priority. The ideal universal vac- cine will protect against all subtypes of influenza A viruses and both lineages of influenza B. Nevertheless, influenza $\mathrm{A}$ and $\mathrm{B}$ have significant genetic and antigenic differences, and the construction of a single vaccine that provides protection against both genera seems to be difficult (Subbarao et al., 2013). Although, the possibility of designing a vaccine against both lineages has emerged due to recently identified, broadly neutralizing antibodies. It is thought that immunity induced against conserved antigens may not necessarily provide protection against infection, but it could decrease the severity of disease, accelerate virus clearance, and reduce morbidity and mortality during the initial stages of a pandemic outbreak until a strain-matched vaccine becomes available (Epstein et al., 2010). It has also been suggested that immunization with such a vaccine could reduce virus transmission from vaccinated, infected animals, thus reducing the size of epidemics. This hypothesis was confirmed in an experimental model in which immunization with a recombinant adenovirus expressing NP and M2, conserved antigens from the influenza virus, significantly reduced the transmission of the virus to co-housed, unimmunized mice (Price et al., 2014).

\section{Acknowledgements}

Funding for the project derives from the European Community funds of the European Fund for Regional Development POIG.01.01.02-00-007/08.

\section{Conflict of interest statement}

The authors declare no competing financial interests.

\section{REFERENCES}

Berthoud TK, Hamill M, Lillie PJ, Hwenda L, Collins KA, Ewer KJ, Milicic A, Poyntz HC, Lambe T, Fletcher HA, Hill AV, Gilbert SC (2011) Potent CD8+ T-cell immunogenicity in humans of a novel heterosubtypic influenza A vaccine, MVA-NP+M1. Clin Infect Dis 52: $1-7$.

Bessa J, Schmitz N, Hinton HJ, Schwarz K, Jegerlehner A, Bachmann MF (2008) Efficient induction of mucosal and systemic immune responses by virus-like particles administered intranasally: implications for vaccine design. Eur J Immunol 38: 114-126.

Blank PR, Bonnelye G, Ducastel A, Szucs TD (2012) Attitudes of the general public and general practitioners in five countries towards pandemic and seasonal influenza vaccines during season 2009/2010. PLos One 7: e45450.

Bommakanti G, Citron MP, Hepler RW, Callahan C, Heidecker GJ, Najar TA, Lu X, Joyce JG, Shiver JW, Casimiro DR, ter Meulen J, Liang X, Varadarajan R (2010) Design of an HA2-based Escherichia coli expressed influenza immunogen that protects mice from pathogenic challenge. Proc Natl Acad Sci USA 107: 13701-13706.

Boyd AC, Ruiz-Hernandez R, Peroval MY, Carson C, Balkissoon D, Staines K, Turner AV, Hill AV, Gilbert SC, Butter C (2013) Towards a universal vaccine for avian influenza: protective efficacy of modified Vaccinia virus Ankara and Adenovirus vaccines expressing conserved influenza antigens in chickens challenged with low pathogenic avian influenza virus. V accine 31: 670-675.

Brewoo JN, Powell TD, Jones JC, Gundlach NA, Young GR, Chu H, Das SC, Partidos CD, Stinchcomb DT, Osorio JE (2013) Crossprotective immunity against multiple influenza virus subtypes by a novel modified vaccinia Ankara (MVA) vectored vaccine in mice. Vaccine 31: 1848-1855.

Carragher DM, Kaminski DA, Moquin A, Hartson L, Randall TD (2008) A novel role for non-neutralizing antibodies against nucleoprotein in facilitating resistance to influenza virus. I Immunol 181: 4168-4176.

Carrat F, Flahault A (2007) Influenza vaccine: the challenge of antigenic drift. Vaccine 25: 6852-6862.

Chen MW, Cheng TJ, Huang Y, Jan JT, Ma SH, Yu AL, Wong CH, Ho DD (2008) A consensus-hemagglutinin-based DNA vaccine that protects mice against divergent $\mathrm{H} 5 \mathrm{~N} 1$ influenza viruses. Proc Natl Acad Sci USA 105: 13538-13543.

Clementi N, De Marco D, Mancini N, Solforosi L, Moreno GJ, Gubareva LV, Mishin V, Di Pietro A, Vicenzi E, Siccardi AG, Clementi M, Burioni R (2011) A human monoclonal antibody with 
neutralizing activity against highly divergent influenza subtypes. PLoS One 6: e28001.

Corti D, Lanzavecchia A (2013) Broadly neutralizing antiviral antibodies. Annu Rev Immunol 31: 705-742.

Corti D, Suguitan AL Jr, Pinna D, Silacci C, Fernandez-Rodriguez BM, Vanzetta F, Santos C, Luke CJ, Torres-Velez FJ, Temperton NJ, Weiss RA, Sallusto F, Subbarao K, Lanzavecchia A (2010) Heterosubtypic neutralizing antibodies are produced by individuals immunized with a seasonal influenza vaccine. J Clin Invest 120: 1663-1673.

Corti D, Voss J, Gamblin SJ, Codoni G, Macagno A, Jarrossay D, Vachieri SG, Pinna D, Minola A, Vanzetta F, Silacci C, FernandezRodriguez BM, Agatic G, Bianchi S, Giacchetto-Sasselli I, Calder L, Sallusto F, Collins P, Haire LF, Temperton N, Langedijk JP, Skehel JJ, Lanzavecchia A (2011) A neutralizing antibody selected from plasma cells that binds to group 1 and group 2 influenza A hemagglutinins. Science 333: 850-856.

Couch RB, Kasel JA, Gerin JL, Schulman JL, Kilbourne ED (1974) Induction of partial immunity to influenza by a neuraminidase-specific vaccine. I Infect Dis 129: 411-420.

Cox NJ, Subbarao K (1999) Influenza. Lancet 354: 1277-1282.

de Filette M, Min Jou W, Birkett A, Lyons K, Schultz B, Tonkyro A, Resch S, Fiers W (2005) Universal influenza A vaccine: optimization of M2-based constructs. Virology 337: 149-161.

de Filette M, Ramne A, Birkett A, Lycke N, Löwenadler B, Min Jou W, Saelens X, Fiers W (2006) The universal influenza vaccine M2e$\mathrm{HBc}$ administered intranasally in combination with the adjuvant CTA1-DD provides complete protection. Vaccine 24: 544-551.

de Jong JC, Beyer WE, Palache AM, Rimmelzwaan GF, Osterhaus AD (2000) Mismatch between the 1997/1998 influenza vaccine and the major epidemic $\mathrm{A}(\mathrm{H} 3 \mathrm{~N} 2)$ virus strain as the cause of an inadequate vaccine-induced antibody response to this strain in the elderly. $J$ Med Virol 61: 94-99.

Dreyfus C, Laursen NS, Kwaks T, Zuijdgeest D, Khayat R, Ekiert DC, Lee JH, Metlagel Z, Bujny MV, Jongeneelen M, van der Vlugt R, Lamrani M, Korse HJ, Geelen E, Sahin Ö, Sieuwerts M, Brakenhoff JP, Vogels R, Li OT, Poon LL, Peiris M, Koudstaal W, Ward AB, Wilson IA, Goudsmit J, Friesen RH (2012) Highly conserved protective epitopes on influenza B viruses. Science 337: 1343-1348.

Ekiert DC, Bhabha G, Elsliger MA, Friesen RH, Jongeneelen M, Throsby M Goudsmit J, Wilson IA (2009) Antibody recognition of a highly conserved influenza virus epitope. Science 324: 246-251.

Ekiert DC, Friesen RH, Bhabha G, Kwaks T, Jongeneelen M, Yu W, Ophorst C, Cox F, Korse HJ, Brandenburg B, Vogels R, Brakenhoff JP, Kompier R, Koldijk MH, Cornelissen LA, Poon LL, Peiris M, Koudstaal W, Wilson IA, Goudsmit J (2011) A highly conserved neutralizing epitope on group 2 influenza a viruses. Science 333: 843-850.

Ekiert DC, Kashyap AK, Steel J, Rubrum A, Bhabha G, Khayat R, Lee JH, Dillon MA, O’Neil RE, Faynboym AM, Horowitz M, Horowitz L, Ward AB, Palese P, Webby R, Lerner RA, Bhatt RR, Wilson IA (2012) Cross-neutralization of influenza A viruses mediated by a single antibody loop. Nature 489: 526-532.

El Bakkouri K, Descamps F, De Filette M, Smet A, Festjens E, Birkett A, Van Rooijen N, Verbeek S, Fiers W, Saelens X (2001) Universal vaccine based on ectodomain of matrix protein 2 of influenza A: Fc receptors and alveolar macrophages mediate protection. I Immunol 186: $1022-1031$.

Epstein SL (2003) Control of influenza virus infection by immunity to conserved viral features. Expert Rev Anti-Infect Ther 1: 627-638.

Epstein SL, Price GE (2010) Cross-protective immunity to influenza A viruses. Expert Rev Vaccines 9: 1325-1341.

Ernst WA, Kim HJ, Tumpey TM, Jansen AD, Tai W, Cramer DV, Adler-Moore JP, Fujii G (2006) Protection against H1, H5, H6 and H9 influenza A infection with liposomal matrix 2 epitope vaccines. Vaccine 24: 5158-5168.

Fan J, Liang X, Horton MS, Perry HC, Citron MP, Heidecker GJ, Fu TM, Joyce J, Przysiecki CT, Keller PM, Garsky VM, Ionescu R, Rippeon Y, Shi L, Chastain MA, Condra JH, Davies ME, Liao J, Emini EA, Shiver JW (2004) Preclinical study of influenza virus A M2 peptide conjugate vaccines in mice, ferrets, and rhesus monkeys. Vaccine 22: 2993-3003.

Fiers W, De Filette M, Birkett A, Neirynck S, Min Jou W (2004) A "universal" human influenza A vaccine. Virus Res 103: 173-176.

Fiore AE, Uyeki TM, Broder K, Finelli L, Euler GL, Singleton JA, Iskander JK, Wortley PM, Shay DK, Bresee JS, Cox NJ (2010) Prevention and control of influenza with vaccines: recommendations of the Advisory Committee on Immunization Practices (ACIP), 2010. Centers for Disease Control and Prevention (CDC) MMWR Recomm Rep 59: 1-62.

Friesen RH, Lee PS, Stoop EJ, Hoffman RM, Ekiert DC, Bhabha G, Yu W, Juraszek J, Koudstaal W, Jongeneelen M, Korse HJ, Ophorst C, Brinkman-van der Linden EC, Throsby M, Kwakkenbos MJ, Bakker AQ, Beaumont T, Spits H, Kwaks T, Vogels R, Ward AB, Goudsmit J, Wilson IA (2014) A common solution to group 2 influenza virus neutralization. Proc Natl Acad Sci U S A 111: 445-450.
Fu TM, Grimm KM, Citron MP, Freed DC, Fan J, Keller PM, Shiver JW, Liang X, Joyce JG (2009) Comparative immunogenicity evaluations of influenza A virus M2 peptide as recombinant virus like particle or conjugate vaccines in mice and monkeys. Vaccine 27:14401447.

Gerhard W, Mozdzanowska K, Zharikova D (2006) Prospects for universal influenza virus vaccine. Emerg Infect Dis 12: 569-574.

Hampson AW, Mackenzie JS (2006) The influenza viruses. Med J Aust 185: S39-S43.

Han T, Marasco WA (2011) Structural basis of influenza virus neutralization. Ann NY Acad Sci 1217: 178-190.

Hay AJ, Gregory V, Douglas AR, Lin YP (2001) The evolution of human influenza viruses. Philos Trans R Soc Lon B Biol Sci 356: 18611870.

Hayashida H, Toh H, Kikuno R, Miyata T (1985) Evolution of influenza virus genes. Mol Biol Evol 2 :289-303.

Heinen PP, Rijsewijk FA, de Boer-Luijtze EA, Bianchi AT (2002) Vaccination of pigs with a DNA construct expressing an influenza virus M2-nucleoprotein fusion protein exacer- bates disease after challenge with influenza A virus. J Gen Virol 83: 1851-1859.

Heiny AT, Miotto O, Srinivasan KN, Khan AM, Zhang GL, Brusic V, Tan TW, August JT (2007) Evolutionarily conserved protein sequences of influenza a viruses, avian and human, as vaccine targets. PLos One 2: e1190.

Hessel A, Savidis-Dacho H, Coulibaly S, Portsmouth D, Kreil TR, Crowe BA, Schwendinger MG, Pilz A, Barrett PN, Falkner FG, Schäfer B (2014) MVA vectors expressing conserved influenza proteins protect mice against lethal challenge with H5N1, H9N2 and H7N1 viruses. PLos One 9: e88340.

Hikono $\mathrm{H}$, Miyazaki A, Mase M, Inoue M, Hasegawa M, Saito T (2012) Induction of a cross- reactive antibody response to influenza virus $\mathrm{m} 2$ antigen in pigs by using a sendai virus vector. Vet Immunol Immunopathol 146: 92-96.

Hoag H (2013) A universal problem. Nature Medicine 19: 12-14.

Huber VC (2013) Influenza vaccines: From whole virus preparations to recombinant protein technology. Expert Rev Vaccine 13: 31-42.

Huleatt JW, Nakaar V, Desai P, Huang Y, Hewitt D, Jacobs A, Tang J, McDonald W, Song L, Evans RK, Umlauf S, Tussey L, Powell TJ (2008) Potent immunogenicity and efficacy of a universal influenza vaccine candidate comprising a recombinant fusion protein linking influenza M2e to the TLR5 ligand flagellin. Vaccine 26: 201-214.

Ionescu RM, Przysiecki CT, Liang X, Garsky VM, Fan J, Wang B, Troutman R, Rippeon Y, Flanagan E, Shiver J, Shi L (2006) Pharmaceutical and immunological evaluation of human papilloma virus virus like particle as an antigen carrier. J Pharm Sci 95: 70-79.

Jefferson T, Di Pietrantonj C, Rivetti A, Bawazeer GA, Al-Ansary LA, Ferroni E (2010) Vaccines for preventing influenza in healthy adults. Cocbrane Database Sys Rev 7: CD001269.

Jegerlehner A, Schmitz N, Storni T, Bachmann MF (2004) Influenza A vaccine based on the extracellular domain of M2: weak protection mediated via antibody-dependent NK cell activity. I Immunol 172: 5598-5605.

Johansson BE, Cox MM (2011) Influenza viral neuraminidase: the forgotten antigen. Expert Rev V accines 10: 1683-1695.

Kanegae Y, Sugita S, Endo A, Ishida M, Senya S, Osako K, Nerome K, Oya A (1990) Evolutionary pattern of the hemagglutinin gene of influenza B viruses isolated in Japan: cocirculating lineages in the same epidemic season. J Virol 64: 2860-2865.

Kashyap AK, Steel J, Oner AF, Dillon MA, Swale RE, Wall KM, Perry KJ, Faynboym A, Ilhan M, Horowitz M, Horowitz L, Palese P, Bhatt RR, Lerner RA (2008) Combinatorial antibody libraries from survivors of the Turkish H5N1 avian influenza outbreak reveal virus neutralization strategies. Proc Natl Acad Sci U S A. 105: 5986-91.

Khurana S, Loving CL, Manischewitz J, King LR, Gauger PC, Henningson J, Vincent AL, Golding H (2013) Vaccine-induced antiHA2 antibodies promote virus fusion and enhance influenza virus respiratory disease. Sci Transl Med 5: 200 ra114.

Kilbourne ED, Laver WG, Schulman JL, Webster RG (1968) Antiviral activity of antiserum specific for an influenza virus neuraminidase. $J$ Virol 2: 281-288.

Kim MC, Song JM, O E, Kwon YM, Lee YJ, Compans RW, Kang SM (2013) Virus-like particles containing multiple M2 extracellular domains confer improved cross-protection against various subtypes of influenza virus. Mol Ther 21: 485-492.

Kissling E, Valenciano M, Buchholz U, Larrauri A, Cohen JM, Nunes B, Rogalska J, Pitigoi D, Paradowska-Stankiewicz I, Reuss A, Jiménez-Jorge S, Daviaud I, Guiomar R, O’Donnell J, Necula G, Głuchowska M, Moren A (2014) Influenza vaccine effectiveness estimates in Europe in a season with three influenza type/subtypes circulating: the I-MOVE multicentre case-control study, influenza season 2012/13. Eurosurveillance 19.

Kissling E, Valenciano M (2011) I-MOVE case-control studies team. Early estimates of seasonal influenza vaccine effectiveness in Europe, 2010/11: I-MOVE, a multicentre case-control study. Eurosurveillance 16. 
Kissling E, Valenciano M, Cohen JM, Oroszi B, Barret AS, Rizzo C, Stefanoff P, Nunes B, Pitigoi D, Larrauri A, Daviaud I, Horvath JK, O’Donnell J, Seyler T, Paradowska-Stankiewicz IA, Pechirra P, Ivanciuc AE, Jiménez-Jorge S, Savulescu C, Ciancio BC, Moren A (2011) I-MOVE multi-centre case control study 2010-11: overall and stratified estimates of influenza vaccine effectiveness in Europe. PLoS One 6: e27622.

Krammer F, Palese P (2014) Universal influenza virus vaccines: need for clinical trials. Nat Immunol 15: 3-5.

Krammer F, Pica N, Hai R, Tan GS, Palese P (2012) Hemagglutinin stalk-reactive antibodies are boosted following sequential infection with seasonal and pandemic H1N1 influenza virus in mice. J Virol 86: 10302-10307.

Krystal M, Elliott RM, Benz EW Jr, Young JF, Palese P (1982) Evolution of influenza $A$ and $B$ viruses: Conservation of structural features in the hemagglutinin genes. Proc Natl Acad Sci U S 79: 4800-4804.

Lamb RA, Krug RM (2001) Orthomyxoviridae: the viruses and their replication. In Fields Virology. Knipe DM, Howley PM, Griffin DE, eds, pp 1487-1531. Lippincott, Philadelphia.

Lamb RA, Zebedee SL, Richardson CD (1985) Influenza virus M2 protein is an integral membrane protein expressed on the infectedcell surface. Cell 40: 627-633.

Lee PS, Yoshida R, Ekiert DC, Sakai N, Suzuki Y, Takada A, Wilson IA (2012) Heterosubtypic antibody recognition of the influenza virus hemagglutinin receptor binding site enhanced by avidity. Proc Natl Acad Sci USA 109: 17040-17045.

Lillie PJ, Berthoud TK, Powell TJ, Lambe T, Mullarkey C, Spencer AJ, Hamill M, Peng Y, Blais ME, Duncan CJ, Sheehy SH, Havelock T, Faust SN, Williams RL, Gilbert A, Oxford J, Dong T, Hill AV, Gilbert SC (2012) Preliminary assessment of the efficacy of a Tcell-based influenza vaccine, MVA-NP+M1, in humans. Clin Infect Dis 55: 19-25.

Liu W, Zou P, Ding J, Lu Y, Chen YH (2005) Sequence comparison between the extracellular domain of M2 protein human and avian influenza A virus provides new information for bivalent influenza vaccine design. Microbes Infect 7:171-177.

Lu Y, Welsh JP, Swartz JR (2014) Production and stabilization of the trimeric influenza hemagglutinin stem domain for potentially broadly protective influenza vaccines. Proc Natl Acad Sci U S A 111: 125-130.

McMichael AJ, Gotch FM, Noble GR, Beare PA (1983) Cytotoxic Tcell immunity to influenza. N Engl J Med 309: 13-17.

Medina R A, A. Garcia-Sastre (2011) Influenza A viruses: new research developments. Nature reviews Microbiology 9: 590-603.

Mereckiene J, Cotter S, Nicoll A, Lopalco P, Noori T, Weber JT , D'Ancona F, Lévy-Bruhl D, Dematte L, Giambi C, ValentinerBranth P, Stankiewicz I, Appelgren E, O'Flanagan D, the VENICE project gatekeepers group (2014) Seasonal influenza immunisation in Europe. Overview of recommendation and vaccination coverage for three seasons pre-pandemic (2008/09), pandemic (2009/10) and post-pandemic (2010/11). Eurosurveillance 19.

Miller MS, Tsibane T, Krammer F, Hai R, Rahmat S, Basler CF, Palese P (2013) 1976 and 2009 H1N1 influenza virus vaccines boost antihemagglutinin stalk antibodies in humans. J Infect Dis 207: 98-105.

Moriuchi H, Katsushima N, Nishimura H, Nakamura K, Numazaki Y (1991) Community-acquired influenza $C$ virus infection in children. J Pediatr118: 235-238.

Murphy BR, Kasel JA, Chanock RM 1972) Association of serum antineuraminidase antibody with resistance to influenza in man. $N$ Engl J Med 286: 1329-1332.

Neirynck S, Deroo T, Saelens X, Vanlandschoot P, Jou WM, Fiers W (1999) A universal influenza A vaccine based on the extracellular domain of the M2 protein. Nat Med 5: 1157-1163.

Nichol KL, Nordin JD, Nelson DB, Mullooly JP, Hak E (2007) Effectiveness of influenza vaccine in the community-dwelling elderly. N Engl J Med 357: 1373-1381.

Nicoll A, Sprenger M (2013) Low effectiveness undermines promotion of seasonal influenza vaccine. Lancet Infect Dis 13: 7-9.

Ohshima N, Iba Y, Kubota-Koketsu R, Asano Y, Okuno Y, Kurosawa $\mathrm{Y}$ (2011) Naturally occurring antibodies in humans can neutralize a variety of influenza virus strains, including $\mathrm{H} 3, \mathrm{H} 1, \mathrm{H} 2$, and $\mathrm{H} 5 . J$ Virol 85: 11048-11057.

Okuno Y, Isegawa Y, Sasao F, Ueda S (1993) A common neutralizing epitope conserved between the hemagglutinins of influenza A virus H1 and H2 strains. J Virol 67: 2552-2558.

Osterholm MT, Kelley NS, Sommer A, Belongia EA (2012) Efficacy and effectiveness of influenza vaccines: a systematic review and meta-analysis. Lancet Infect Dis. 12: 36-44.

Peter D Kwong, Ian A Wilson (2009) HIV-1 and influenza antibodies: seeing antigens in new ways. Nat Immunol 10: 573-578.

Pica N, Hai R, Krammer F, Wang TT, Maamary J, Eggink D, Tan GS, Krause JC, Moran T, Stein CR, Banach D, Wrammert J, Belshe RB, García-Sastre A, Palese P (2012) Hemagglutinin stalk antibodies elicited by the 2009 pandemic influenza virus as a mechanism for the extinction of seasonal H1N1 viruses. Proc Natl Acad Sci USA 109: 2573-2578.

Pica N, Palese P (2013) Toward a universal influenza virus vaccine: Prospects and challenges. Ann Rev Med 64: 189-202.

Powers DC, Kilbourne ED, Johansson BE (1996) Neuraminidasespecific antibody responses to inactivated influenza virus vaccine in young and elderly adults. Clin Diagn Lab Immunol 3: 511-516.

Price GE, Lo CY, Misplon JA, Epstein SL (2014) Mucosal immunization with a candidate universal influenza vaccine reduces virus transmission in a mouse model. J Virol 88: 6019-6030.

Price GE, Soboleski MR, Lo CY, Misplon JA, Pappas C, Houser KV, Tumpey TM, Epstein SL (2009) Vaccination focusing immunity on conserved antigens protects mice and ferrets against virulent H1N1 and H5N1 influenza A viruses. Vaccine 27: 6512-6521.

Quan FS, Kim MC, Lee BJ, Song JM, Compans RW, Kang SM (2012) Influenza M1 VLPs containing neuraminidase induce heterosubtypic cross-protection. Virology 430: 127-135.

Reid AH, Fanning TG, Janczewski TA, McCall S, Taubenberger JK (2012) Characterization of the 1918 "Spanish" influenza virus matrix gene segment. J Virol. 76: 10717-10723.

Rossman JS, Lamb RA (2011) Influenza virus assembly and budding. Virology 411: 229-236.

Rota PA, Wallis TR, Harmon MW, Rota JS, Kendal AP, Nerome K. (1990) Cocirculation of two distinct evolutionary lineages of influenza type B virus since 1983. Virology 175: 59-68.

Russ G, Poláková K, Kostolanský F, Styk B, Vancíková M (1987) Monoclonal antibodies to glycopolypeptides HA1 and HA2 of influenza virus haemagglutinin. Acta Virol 31: 374-386.

Russell CA, Jones TC, Barr IG, Cox NJ, Garten RJ, Gregory V, Gust ID, Hampson AW, Hay AJ, Hurt AC, de Jong JC, Kelso A, Klimov AI, Kageyama T, Komadina N, Lapedes AS, Lin YP, Mosterin A, Obuchi M, Odagiri T, Osterhaus AD, Rimmelzwaan GF, Shaw MW, Skepner E, Stohr K, Tashiro M, Fouchier RA, Smith DJ (2008) Influenza vaccine strain selection and recent studies on the global migration of seasonal influenza viruses. Vaccine 26: 31-34.

Russell CJ (2011) Stalking influenza diversity with a universal antibody. N Engl J Med 365: 1541-1542.

Sagawa H, Ohshima A, Kato I, Okuno Y, Isegawa Y. (1996) The immunological activity of a deletion mutant of influenza virus haemagglutinin lacking the globular region. J Gen Virol 77: 1483-1487.

Sakabe S, Iwatsuki-Horimoto K, Horimoto T, Nidom CA, Le MQ, Takano R, Kubota-Koketsu R, Okuno Y, Ozawa Kawaoka Y (2010) A cross-reactive neutralizing monoclonal antibody protects mice from H5N1 and pandemic (H1N1) 2009 virus infection. Antiviral Res 88: 249-255.

Schneemann A, Speir JA, Tan GS, Khayat R, Ekiert DC, Matsuoka Y, Wilson IA (2012) A Virus-like particle that elicits cross-reactive antibodies to the conserved stem of influenza virus hemagglutinin. I Virol 86: 11686-11697.

Schnell JR, Chou JJ (2008) Structure and mechanism of the M2 proton channel of influenza A virus. Nature 451: 591-595.

Scuffham PA, West PA (2002) Economic evaluation of strategies for the control and management of influenza in Europe. Vaccine 20: 2562-2578.

Shapshak P, Chiappelli F, Somboonwit C, Sinnott J (2011) The influenza pandemic of 2009: Lessons and implications. Mol Diagn Ther 15: $63-81$.

Shu LL, Bean WJ, Webster RG (1993) Analysis of the evolution and variation of the human influenza A virus nucleoprotein gene from 1933 to 1990 . J Virol 67: 2723-2729.

Skowronski DM, Janjua NZ, De Serres G, Sabaiduc S, Eshaghi A, Dickinson JA, Fonseca K, Winter AL, Gubbay JB, Krajden M, Petric M, Charest $H$, Bastien N, Kwindt TL, Mahmud SM, Van Caeseele P, Li Y (2014) Low 2012-13 Influenza vaccine effectiveness associated with mutation in the egg-adapted $\mathrm{H} 3 \mathrm{~N} 2$ vaccine strain not antigenic drift in circulating viruses. PLoS One 9: e92153.

Slepushkin VA, Katz JM, Black RA, Gamble WC, Rota PA, Cox NJ (1995) Protection of mice against influenza A virus challenge by vaccination with baculovirus-expressed M2 protein. Vaccine 13: 1399-1402.

Smirnov YA, Lipatov AS, Gitelman AK, Okuno Y, Van Beek R, Osterhaus AD, Claas EC (1999) An epitope shared by the hemagglutinins of $\mathrm{H} 1, \mathrm{H} 2, \mathrm{H} 5$, and $\mathrm{H} 6$ subtypes of influenza A virus. Acta Virol 43: 237-244.

Song JM, Wang BZ, Park KM, Van Rooijen N, Quan FS, Kim MC, Jin HT, Pekosz A, Compans RW, Kang SM (2011) Influenza viruslike particles containing M2 induce broadly cross protective immunity. PLoS One 6: e14538.

Steel J, Lowen AC, Wang T'T, Yondola M, Gao Q, Haye K, GarcíaSastre A, Palese P. (2010) Influenza virus vaccine based on the conserved hemagglutinin stalk domain. MBio 1: e00018-10.

Subbarao K, Matsuoka Y. Trends Microbiol (2013) The prospects and challenges of universal vaccines for influenza. Trends Microbiol 21: 350-358.

Sui J, Hwang WC, Perez S, Wei G, Aird D, Chen LM, Santelli E, Stec B, Cadwell G, Ali M, Wan H, Murakami A, Yammanuru A, Han 
T, Cox NJ, Bankston LA, Donis RO, Liddington RC, Marasco WA (2009) Structural and functional bases for broad-spectrum neutralization of avian and human influenza A viruses. Nat Struct Mol Biol 16: $265-273$.

Sui J, Sheehan J, Hwang WC, Bankston LA, Burchett SK, Huang CY, Liddington RC, Beigel JH, Marasco WA (2011) Wide prevalence of heterosubtypic broadly neutralizing human anti-influenza A antibodies. Clin Infect Dis 52: 1003-1009.

Talbot HK, Rock MT, Johnson C, Tussey L, Kavita U, Shanker A, Shaw AR, Taylor DN (2010) Immunopotentiation of trivalent influenza vaccine when given with VAX102, a recombinant influenza M2e vaccine fused to the TLR5 ligand flagellin. PLoS One 5: e14442.

Thompson WW, Shay DK, Weintraub E, Brammer L, Bridges CB, Cox NJ, Fukuda K (2004) Influenza-associated hospitalizations in the United States. JAMA 292: 1333-1340.

Throsby M, van den Brink E, Jongeneelen M, Poon LL, Alard P, Cornelissen L, Bakker A, Cox F, van Deventer E, Guan Y, Cinatl J, ter Meulen J, Lasters I, Carsetti R, Peiris M, de Kruif J, Goudsmit $\mathrm{J}$ (2008) Heterosubtypic neutralizing monoclonal antibodies crossprotective against $\mathrm{H} 5 \mathrm{~N} 1$ and $\mathrm{H} 1 \mathrm{N1}$ recovered from human IgM+ memory B cells. PLoS One 3: e3942.

To KK, Zhang AJ, Hung IF, Xu T, Ip WC, Wong RT, Ng JC, Chan JF, Chan KH, Yuen KY (2012) High titer and avidity of nonneutralizing antibodies against influenza vaccine antigen are associated with severe influenza. Clin Vaccine immunol 19: 1012-1018.

Tompkins SM, Zhao ZS, Lo CY, Misplon JA, Liu T, Ye Z, Hogan RJ, Wu Z, Benton KA, Tumpey TM, Epstein SL (2007) Matrix protein 2 vac- cination and protection against influenza viruses, inclu- ding subtype H5N1. Emerg Infect Dis 13: 426-435.

Tong S, Zhu X, Li Y, Shi M, Zhang J, Bourgeois M, Yang H, Chen X, Recuenco S, Gomez J, Chen LM, Johnson A, Tao Y, Dreyfus C, Yu W, McBride R, Carney PJ, Gilbert AT, Chang J, Guo Z, Davis CT, Paulson JC, Stevens J, Rupprecht CE, Holmes EC, Wilson IA, Donis RO (2013) New world bats harbor diverse influenza a viruses. PLOS Pathog 9.

Treanor JJ, Tierney EL, Zebedee SL, Lamb RA, Murphy BR (1990) Passively transferred monoclonal antibody to the M2 protein inhibits influenza A virus replication in mice. J Virol 64: 1375-1377.

Tsibane T, Ekiert DC, Krause JC, Martinez O, Crowe JE Jr, Wilson IA, Basler CF (2012) Influenza human monoclonal antibody 1F1 interacts with three major antigenic sites and residues mediating human receptor specificity in H1N1 viruses. PLoS Patog 8: e1003067

Turley CB, Rupp RE, Johnson C, Taylor DN, Wolfson J, Tussey L, Kavita U, Stanberry L, Shaw A (2011) Safety and immunogenicity of a recombinant M2e-flagellin influenza vaccine (STF2.4xM2e) in healthy adults. Vaccine 29: 5145-5152.
Ulmer JB, Fu TM, Deck RR, Friedman A, Guan L, DeWitt C, Liu X, Wang S, Liu MA, Donnelly JJ, Caulfield MJ (1998) Protective CD4+ and CD8+ $\mathrm{T}$ cells against influenza virus induced by vaccination with nucleoprotein DNA. J Virol 72: 5648-5653.

Wang R, Song A, Levin J, Dennis D, Zhang NJ, Yoshida H, Koriazova L, Madura L, Shapiro L, Matsumoto A, Yoshida H, Mikayama T, Kubo RT, Sarawar S, Cheroutre H, Kato S (2008) Therapeutic potential of a fully human monoclonal antibody against influenza A virus M2 protein. Antiviral Res 80: 168-177.

Wang TT, Tan GS, Hai R, Pica N, Ngai L, Ekiert DC, Wilson IA, García-Sastre A, Moran TM, Palese P (2010) Vaccination with a synthetic peptide from the influenza virus hemagglutinin provides protection against distinct viral subtypes. Proc Natl Acad Sci USA 107: 18979-18984.

Weaver EA, Rubrum AM, Webby RJ, Barry MA (2011) Protection against divergent influenza $\mathrm{H} 1 \mathrm{~N} 1$ virus by a centralized influenza hemagglutinin. PLoS One 6: e18314.

Webster RG, Reay PA, Laver WG (1988) Protection against lethal influenza with neuraminidase. Virology 164: 230-237.

Wiley DC, Wilson IA, Skehel JJ (1981) Structural identification of the antibody-binding sites of Hong Kong influenza haemagglutinin and their involvement in antigenic variation. Nature 289: 373-378.

Wright PF, Webster RG (2001) Orthomyxoviridae: the viruses and their replication. In Fields Virology. Knipe DM, Howley PM, Griffin DE, eds, pp 1533-1579. Lippincott, Philadelphia.

Wu CY, Yeh YC, Chan JT, Yang YC, Yang JR, Liu MT, Wu HS, Hsiao PW. (2012) A VLP vaccine induces broad-spectrum cross-protective antibody immunity against H5N1 and H1N1 subtypes of influenza A virus. PLoS One 7: e42363.

Wu F, Huang JH, Yuan XY, Huang WS, Chen YH (2007) Characterization of immunity induced by M2e of influenza virus. Vaccine 25: 8868-8873.

Wu F, Yuan XY, Li J, Chen YH (2009) The co-administration of CpG-ODN influenced protective activity of influenza M2e vaccine. Vaccine 27: 4320-4324.

Yogev R (2005) Influenza vaccine confusion: a call for an alternative evidence-based approach. Pediatrics 116: 1214-1215.

Zebedee S L, Lamb R A (1988) Influenza A virus M2 protein: monoclonal antibody restriction of virus growth and detection of M2 in virions. J Virol 62: 2762-2772.

Zhou H, Thompson WW, Viboud CG, Ringholz CM, Cheng PY, Steiner C, Abedi GR, Anderson LJ, Brammer L, Shay DK (2012) Hospitalizations associated with influenza and respiratory syncytial virus in the United States, 1993-2008. Clin Infect Dis 54: 1427-1436. 